\title{
Successful Latin American initiatives in biophysics
}

\author{
Marcelo M. Morales • Silvia del V. Alonso
}

Received: 10 February 2014 / Accepted: 10 February 2014 / Published online: 1 March 2014

(C) International Union for Pure and Applied Biophysics (IUPAB) and Springer-Verlag Berlin Heidelberg 2014

\section{Editorial}

The Latin American Federation of Biophysical Societies (LAFeBS) was founded in 2007 to encourage the development and dissemination of knowledge in biophysics. The Federation comprises biophysical societies and groups of researchers from the following countries: Argentina, Brazil, Colombia, Portugal, Spain, Uruguay, and Venezuela. The number of members of the societies and groups associated with LAFeBS is now around 2,000, and they work mainly in academia, industry, and government agencies throughout Latin America and the Iberian Peninsula.

The Federation holds a meeting every 3 years, bringing together over 500 researchers in the multidisciplinary fields representing biophysics. The Federation provides the Latin American Postgraduate Program of Biophysics (POSLATAM) together with International Union for Pure and Applied Biophysics (IUPAB). POSLATAM, currently coordinated by Dr Marcelo Morales (Brazil), is the first regional initiative at postgraduate level in Latin America and already has 257 students (masters and PhD students from more than 30 postgraduate programs associated with POSLATAM from Argentina, Brazil, Colombia, Uruguay and Venezuela). POSLATAM also sponsors thematic and annual courses, workshops, and conferences in Latin America.

Article for SI Successful Latin American Initiatives in Biophysics

M. M. Morales $(\bowtie)$

Laboratory of Cellular and Molecular Physiology, Carlos Chagas

Filho Institute of Biophysics, Federal University of Rio de Janeiro,

Rio de Janeiro, Brazil

e-mail: mmorales@biof.ufrj.br

S. del V. Alonso

Biomembrane Laboratory, Departamento de Ciencia y Tecnología,

Universidad Nacional de Quilmes, Buenos Aires;

IMBICE-CONICET, La Plata, Argentina
Membership of LAFeBS is open to biophysics groups who share the stated purpose of the Federation, related to educational, research, or practical experience in biophysics or in an allied scientific field (information at http://www.lafebs.org). Categories of membership include active associated bodies (societies) and biophysics groups. The main objective of LAFeBS is to promote discussion and interaction between Latin American and Iberian Peninsula Societies of Biophysics for the mutual development of biophysics. The current office holders (2012-2015) are Dr Silvia del V. Alonso, Argentina (LAFeBS President), Dr Marcelo Morales, Brazil (General Secretary and Past-President), and Dr. Luis Gonzalez Flecha, Argentina (Treasurer); the office of the Federation is located at the Federal University of Rio de Janeiro, Rio de Janeiro, Brazil.

The II LAFeBS Congress together with the XXXVII Congress of the Brazilian Biophysical Society (SBBf) (www. lafebs.org/congresso2012) was held in Búzios, Rio de Janeiro, Brazil, from October 24 to 27, 2012. We had 500 participants and speakers from Argentina, Brazil, Uruguay, United States, Chile, Colombia, Belgium, Venezuela, Spain, Portugal, and Switzerland. Their participation significantly contributed to the quality of the LAFeBS/SBBf Congress. The meeting was a joint effort between the Brazilian Biophysical Society and Latin American Federation of Biophysical Societies, including local biophysical societies from Brazil, Argentina, Spain, and Portugal.

The Brazilian Biophysical Society (SBBf), the Argentinean Biophysical Society (SAB), the Spanish Biophysical Society (SBE), and the Portuguese Biophysical Society (SPBf), as well as biophysical groups from Venezuela and Uruguay, have already joined LAFeBS. So the Federation now includes not only Latin American countries but also Portugal and Spain.

The II LAFeBS Congress aimed to promote a closer interaction between Latin American and Iberian Peninsula scientists in their respective fields of research, from structural proteomics to molecular bioenergetics. 
The speakers at this event reflected the importance and development of Biophysics in Latin American Countries, including Portugal and Spain; with 13 of them being invited to write review articles for this special issue of Biophysical Reviews.

We hope that the integration of biophysics and biophysicists in Latin America, together with Portugal and Spain, through LAFeBS and POSLATAM can contribute to the future development of biophysics in these two historical partner regions.

Information about LAFeBS and POSLATAM can be found at http://www.lafebs.org.

Conflict of interest None 